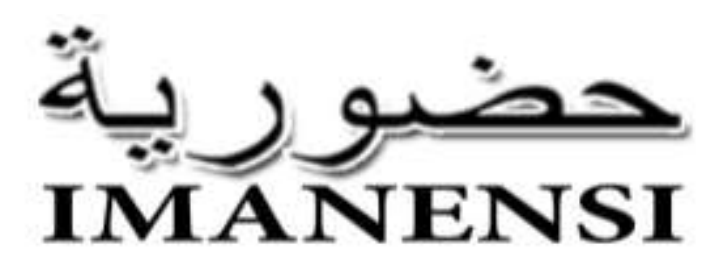

Jurnal Ekonomi, Manajemen, dan Akuntansi Islam

Vol 5, No 1, Maret 2020, Hlmn. 53-60

\title{
Determinan ketepatan waktu pelaporan keuangan perusahaan pertambangan indonesia
}

\section{Tifannya \\ Sri Rahayub ${ }^{\text {* }}$ \\ Reni Yustienc}

abcJurusan Akuntansi, Universitas Jambi, Mendalo Darat, Jambi Indonesia 36122

*sri_rahayu@unja.ac.id; srijambi@gmail.com

*penulis koresponden

10.34202/imanensi.5.1.2020.53-60.

\begin{abstract}
Abstrak
Penelitian ini bertujuan untuk menganalisis pengaruh debt to equity ratio profltabilitas, pergantian auditor dan ukuran perusahaan terhadap ketepatan waktu pelaporan keuangan. Perusahaan pertambangan yang terdaftar di Bursa Efek Indonesia pada tahun 2014-2017 dipilih sebagai populasi penelitian. Metode pengambilan sampel adalah purposive sampling. Data dianalisis dengan regresi logistik. Hasil penelitian menunjukkan bahwa secara parsial, profitabilitas dan pergantian auditor memengaruhi ketepatan waktu pelaporan keuangan sedangkan variabel debt to equity ratio dan ukuran perusahaan tidak memeengaruhi ketepatan waktu pelaporan keuangan. Secara simultan keseluruhan variabel independen berpengaruh terhadap ketepatanwaktuan pelaporan keuangan.
\end{abstract}

Kata Kunci: Profitabilitas; pelaporan keuangan; pergantian audior

\section{Abstract}

This study aims to analyze the effect of debt to equity ratio, profitability, auditor switching and size on the timeliness of financial reporting. Mining companies listed on the Indonesia Stock Exchange in 2014-2017 were selected as the study population. The sampling method is purposive sampling. Data were analyzed by logistic regression. The results showed that profitability and auditor turnover affect the timeliness of financial reporting. Debt to equity ratio and size do not affect the timeliness of financial reporting. Simultaneously, all of independent variable affected on the timeliness of financial reporting.

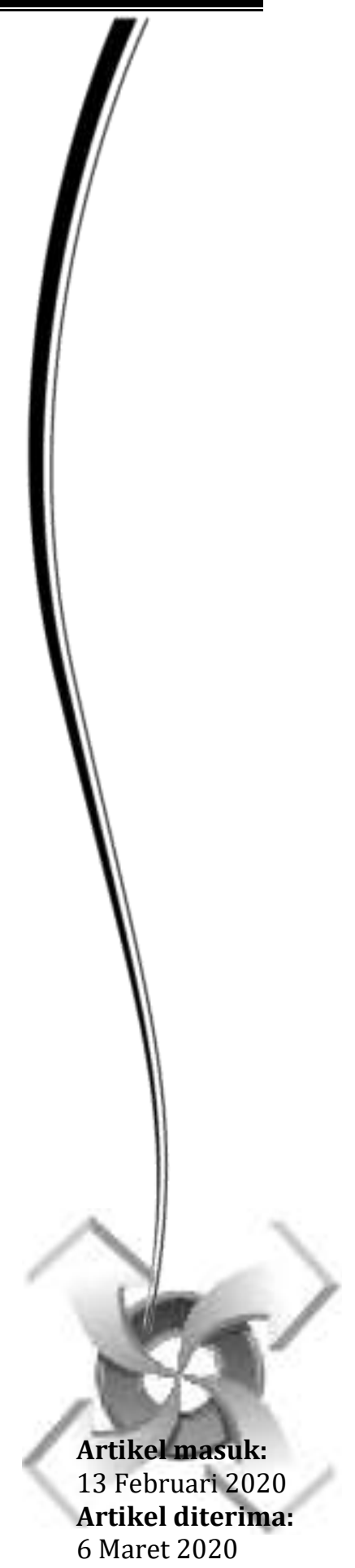

Keywords: Profitability; Financial Reporting; Auditor Switching. 


\section{PENDAHULUAN}

Laporan keuangan menjadi sarana informasi untuk mengkomunikasiakn perkembangan usaha dan kinerja yang telah diperolah selama periode tertentu kepada para investor serta pihak lain yang berkepentingan. Laporan keuangan akan menghasilkan informasi keuangan akurat dan tepat waktu kepada pemakainya, sehingga dapat bermanfaat bagi penggunanya, namun apabila dilaporkan secara tidak tepat waktu maka nilai manfaat tentu saja akan berkurang (Utami \& Yennisa, 2017). Penyajian laporan keuangan tepat waktu (timeliness) menjadi salah satu faktor penting agar infomasi yang disajikan menjadi relevan. Relevansi informasi akan menjadikan informasi dapat digunakan untuk memprediksi masa depan (predictive value), bahan evaluasi sebagai umpan balik (feedback value) dan informasi tersebut tidak kehilangan kapasitas untuk mempengaruhi keputusan yang diambil (Noviatiani \& Asri, 2016). Penyajian informasi secara tepat waktu artinya komunikasi informasi secara lebih awal untuk menghindari adanya kelambatan atau penundaan dalam pengambilan keputusan ekonomi (Belkaoui, 2006). Ketepatan waktu adalah rentang waktu atau lamanya hari yang dibutuhkan untuk mengumumkan laporan keuangan tahunan yang telah diaudit ke publik, sejak tanggal tutup tahun buku perusahaan sampai tanggal penyerahan ke Otoritas Jasa Keuangan (OJK). Ketepatan waktu tidak menjamin relevansi, tetapi relevansi tidak mungkin tercapai tanpa adanya ketepatan waktu. Oleh karena itu, ketepatan waktu adalah batasan penting pada publikasi laporan keuangan.

Pengaruh kualitas informasi dalam pengambilan keputusan menyebabkan perusahaan-perusahaan yang go public harus sesegera mungkin mempublikasikan informasi keuangan yang tersaji dalam laporan keuangannya (Toding \& Wirakusuma, 2013). Ketepatan waktu pelaporan keuangan diatur dalam Peraturan X.K.2 Keputusan Ketua. Bapepam Nomor KEP-346/BL/2011 tentang Penyampaian Laporan Keuangan Berkala Emiten atau Perusahaan Publik. Dalam peraturan tersebut dinyatakan secara jelas bahwa emiten atau perusahaan publik wajib menyampaikan laporan tahunan kepada Bapepam dan LK (sekarang OJK) paling lambat pada akhir bulan ketiga setelah tahun buku berakhir.

Peraturan tersebut tampaknya belum dapat dipatuhi oleh seluruh emiten yang terdaftar di Bursa Efek Indonesia. Hasil pantauan BEI hingga 29 Juni 2015 menunjukkan bahwa terdapat 6 perusahaan tercatat yang belum menyampaikan laporan keuangan auditan per 31 Desember 2014, dan atau belum melakukan pembayaran denda keterlambatan (Sukirno, 2015). Pada tahun 2016, Bursa Efek Indonesia (BEI) membekukan perdagangan saham 18 emiten karena belum menyampaikan laporan keuangan per 31 Desember 2015 atau belum membayar denda atas keterlambatan (Sulistiyono, 2016). Suprayitno (2017) menyatakan bahwa Bursa Efek Indonesia (BEI) menghentikan sementara perdagangan saham delapan emiten dan memperpanjang suspensi untuk sembilan emiten sebagai sanksi akibat belum menyampaikan laporan keuangan audit per 31 Desember 2016. Sementara itu, pada tahun 2018 ada delapan perusahaan terdaftar di BEI yang dijatuhi perpanjangan suspensi perdagangan efek per tanggal 2 Juli 2018 oleh otoritas bursa karena hingga kini belum menyelesaikan kewajibannya terkait dengan pelaporan keuangan serta pembayaran denda atas keterlambatan penyerahan laporan audit (Jatmiko, 2018).

Pihak manajemen cenderung akan menunda penyampaian laporan keuangan yang berisi berita buruk karena waktu yang ada digunakan untuk menekan debt to equity ratio serendah-rendahnya (Dewi \& Jusia, 2013), hal 
ini diperkuat Sanjaya \& Wirawati (2016), Noviatiani \& Asri (2016), dan Putri (2015) yang menyatakan bahwa debt to equity ratio terbukti dapat mempengaruhi penyampaian laporan keuangan secara tepat waktu, sedangkan penelitian yang dilakukan oleh Budiyanto \& Aditya (2015) dan Utami \& Yennisa (2017) menyatakan bahwa debt to equity ratio tidak berpengaruh terhadap ketepatan waktu penyampaian laporan keuangan.

Rasio profitabilitas merupakan rasio untuk menilai kemampuan perusahaan dalam mencari keuntungan (Kasmir, 2010). Perusahaan akan mempercepat penyampaian informasi yang baik ini kepada publik. (Utami \& Yennisa, 2017). Di pihak lain, auditor yang menghadapi perusahaan yang mengalami kerugian cenderung lebih berhati-hati dalam melakukan proses pengauditan (Aprianti, 2017). Hal ini diperkuat oleh Sanjaya \& Wirawati (2016), Dewi \& Wirakusuma (2014), Toding \& Wirakusuma (2013), dan Putri (2015) yang menyatakan bahwa profitabilitas berpengaruh terhadap ketepatan waktu penyampaian laporan keuangan. Di samping itu, Budiyanto \& Aditya (2015) dan Utami \& Yennisa (2017) menyatakan bahwa profitabilitas tidak berpengaruh terhadap ketepatan waktu penyampaian laporan keuangan.

Pergantian Kantor Akuntan Publik bisa bersifat mandatory (wajib) dan bisa juga bersifat voluntary (sukarela). Budiyanto \& Aditya (2015) dan Sanjaya \& Wirawati (2016) menyatakan bahwa pergantian auditor berpengaruh terhadap ketepatan waktu penyampaian laporan keuangan. Demikian juga dengan Ukuran perusahaan, menurut Brigham \& Houston (2010) merupakan ukuran besar kecilnya sebuah perusahaan yang ditunjukan atau dinilai oleh total aset, total penjualan, jumlah laba, beban pajak dan lain-lain. Ukuran aktiva dipakai sebagai wakil pengukur (proxy) besarnya perusahaan (Hartono, 2017). Perusahaan yang besar pastinya memiliki staf yang banyak dan sumber informasi yang canggih, hal tersebut akan memungkinkan perusahaan cepat dalam menyampaikan laporan keuangannya (Carbaja \& Yadnyana, 2015). Toding \& Wirakusuma (2013), Sanjaya \& Wirawati (2016), Noviatiani \& Asri (2016), dan Utami \& Yennisa (2017) memperkuat bahwa ukuran perusahaan memiliki hubungan positif dengan ketepatwaktuan pelaporan keuangan. Sebaliknya Dewi \& Jusia (2013) dan Budiyanto \& Aditya (2015) menyatakan bahwa ukuran perusahaan tidak memiliki pengaruh terhadap ketepatan waktu penyampaian laporan keuangan.

Fenomena-fenomena di atas menunjukkan masih ditemukan perusahaan yang listed di Bursa Efek lndonesia belum tepat waktu dalam menyerahkan annual report kepada OJK. Fenomena ini juga ditemukan pada perusahaan pertambangan. Penyampaian laporan yang tidak tepat waktu ini mencerminkan adanya masalah yang disebabkan oleh good news dan bad news (Oktarini \& Wirakusuma, 2014). Berdasarkan pemaparan di atas, maka penelitian ini bertujuan untuk melakukan pengujian terhadap faktor-faktor yang mempengaruhi ketepatwaktuan pelaporan keuagan untuk perusahaan pertambangan yang listed di Bursa Efek Indonesia.

\section{METODE}

Pendekatan penelitian yang digunakan dalam penelitian ini adalah penelitian kuantitatif. Objek yang akan diteliti dalam penelitian ini adalah variabel yang terkait dalam penelitian yaitu Ketepatan Waktu Penyampaian Laporan Keuangan sebagai variabel dependen, sedangkan debt to equity ratio, profitabilitas, pergantian auditor, dan ukuran perusahaan sebagai variabel independen. Subjek penelitian ini adalah perusahaan pertambangan yang terdaftar di BEI tahun 2014-2017. 
Data sekunder digunakan dalam penelitian ini yang berasal informasi yang ada pada website perusahaan dan sumber lainnya. Data sekunder lainnya berupa laporan keuangan perusahaan pertambangan yang terdaftar di BEI selama tahun 2014 - 2017 yang di akses dari www.idx.co.id.

Populasi penelitian ini adalah perusahaan pertambangan (dari tahun 2014-2017) yang terdaftar di Bursa Efek Indonesia. Teknik penarikan sampel penelitian adalah dengan menggunakan metode purposive sampling yaitu sampel dipilih atas dasar kesesuaian karakteristik sampel dengan kriteria pemilihan sampel yang ditentukan. Sampel yang dipilih dalam penelitian ini adalah perusahaan pertambangan yang tercatat di BEI dengan kriteria (1) Terdaftar di Bursa Efek Indonesia selama periode 2014 - 2017; (2) mempublikasikan laporan tahunan selama periode 2014 - 2017 dan (3) menyajikan data lengkap sesuai variabel yang diteliti. Perusahaan pertambangan yang listed di BEI sebanyak 43 perusahaan. Dari data 43 perusahaan tersebut yang masuk kategori perusahaan sampel penelitian adalah 33 perusahaan, sehingga jumlah sampel total dengan periode penelitian 4 tahun adalah 132 perusahaan. Data dianalisis dengan menggunakan regresi logistic.

\section{HASIL DAN PEMBAHASAN}

\section{A. Analisis Deskriptif}

Peneliti akan mengurai hasil dan pembahasan penelitian dari 33 perusahaan tambang yang digunakan sebagai subyek dalam penelitian ini. Debt to Equity Ratio merupakan perbandingan total hutang yang dimiliki perusahaan dengan modal sendiri (ekuitas) (Kasmir, 2010). Dalam tiga tahun pertama 2014-2016 DOID menjadi perusahaan dengan tingkat DER tertinggi. Hal yang unik terjadi pada BUMI karena untuk tahun 2014-2016 memperoleh DER terendah, dan terjadi kenaikan sangat tinggi di 2017 sehingga menjadi perusahaan dengan DER tertinggi yaitu mencapai 11,91 .

Profitabilitas diproksikan dengan rasio Return on Assets (ROA). Return on Total Assets mengukur kemampuan perusahaan dalam memanfaatkan aktivanya untuk memperoleh laba. Kemampuan perusahaan pertambangan yang listed di BEI tahun 2014-2017 terlihat tahun 2014 CKRA menjadi perusahaan dengan tingkat profitabilitas terendah yaitu $(27,23)$, sedangkan perusahaan dengan tingkat profitabilitas tertinggi dicapai oleh ITMG yaitu 15,31. MYOH menjadi perusahaan dengan tingkat profitabilitas tertinggi tahun 2015 yaitu 15,34 sedangkan MITI dengan tingkat profitabilitas $(72,13)$ menduduki posisi terendah. Tahun 2016, ATPK menjadi perusahaan dengan tingkat profitabilitas terendah yaitu $(18,16)$ dan CKRA kembali berada pada posisi terendah di tahun 2017 dengan posisi $(45,67)$. Profitabilitas tertinggi pada tahun 2016 dan 2017 dicapai oleh BSSR.

Pergantian auditor dapat terjadi karena mandatory sesuai peraturan yang berlaku atau karena keinginan perusahaan sendiri (voluntary). Pada penelitian ini merupakan variabel dummy, dimana perusahaan yang tidak melakukan pergantian auditor termasuk kategori 1, sedangkan apabila perusahaan tersebut melakukan pergantian auditor maka termasuk kategori 0 (Sanjaya \& Wirawati, 2016). Frekuensi pergantian auditor pada perusahaan dapat disimpulkan tidak keseluruhan perusahaan melakukan pergantian auditor selama tahun 2014-2017. Terdapat beberapa perusahaan yang tidak melakukan pergantian auditor yaitu ADRO, BYAN, GEMS, HRUM, ITMG, PTRO, SMRU, TOBA, ESSA, MEDC, MITI, RUIS, ANTM dan TINS. Perusahaan 
lainnya melakukan pergantian pada tahun yang berbeda-beda. PKPK menjadi perusahaan yang melakukan pergantian auditor selama tiga tahun berturutturut yaitu 2014 sampai dengan 2016 .

Jumlah aset yang dimiliki oleh perusahaan dapat digunakan sebagai indikator ukuran perusahaan. Pada penelitian ini, ukuran perusahaan diproksikan dengan menggunakan Ln total aset. Penggunaan Natural log (Ln) (Hartono, 2017). Perusahaan dengan ukuran perusahaan tertinggi selama empat tahun berturut-turut adalah ADRO. Sebaliknya PKPK menjadi perusahaan dengan total aset terendah selama tahun 2014 sampai dengan 2017.

Proksi untuk ketepatan waktu diukur dengan dummy yaitu (1) tepat waktu, yaitu publikasi laporan keuangan kurang dari (90 hari) atau sebelum tanggal 31 maret (tepat waktu) diberi kode 1. (2) Tidak tepat waktu, yaitu publikasi lebih dari (90 hari) atau setelah tanggal 31 maret (tidak tepat waktu) diberi kode 0. Terdapat dua perusahaan yaitu CITA dan CKRA yang tidak tepat waktu dalam pelaporan keuangannya selama tahun 2014-2017.

\section{A. Determinan Ketepatan Waktu Pelaporan Keuangan Perusahaan Pertambangan Indonesia}

Peneliti selanjutnya melakukan pengujian secara statistik. Pengujian regresi logistic dilakukan setelah diyakini bahwa tidak terjadi multikolinearitas. Persamaan regresi logistik yang diperoleh adalah sebagai berikut:

$$
\mathrm{KW}=2,185+\text { 0,134DER + 0,081ROA + 1,060AUD - 0,120SIZE + e }
$$

Berdasarkan persamaan regresi di atas, dapat dilihat bahwa terdapat pengaruh positif untuk keseluruhan variabel independen ke variabel kualitas pelaporan keuangan.

Pada regresi logistik menggunakan nilai Chi-Square dari selisih antara -2 $\log L$ sebelum variabel independen masuk model dan $-2 \log L$ setelah variabel independen masuk model untuk menguji signifikansi simultan. Model regresi semakin baik apabila terjadi penurunan model Log Likelihood.

Nilai Chi-Square adalah sebesar 22,690 (181,898 - 159,209) dengan df 4 (jumlah variabel independen 4) dan signifikansi sebesar 0,000 $<0,05$ (a = $5 \%$ ) yang berarti variabel debt to equity ratio (DER), profitabilitas (ROA), pergantian auditor (AUD), dan ukuran perusahaan (SIZE) berpengaruh terhadap ketepatan waktu pelaporan keuangan (KW) sehingga $\mathrm{H} 1$ diterima.

Tabel 1. Hasil Uji Wald

\begin{tabular}{|c|c|c|c|c|c|c|c|c|c|}
\hline & \multirow[b]{2}{*}{ B } & \multirow[b]{2}{*}{ S.E. } & \multirow[b]{2}{*}{ Wald } & \multirow[b]{2}{*}{$\mathrm{df}$} & \multirow[b]{2}{*}{ Sig. } & \multirow[b]{2}{*}{$\operatorname{Exp}(B)$} & \multicolumn{2}{|c|}{ 95\% C.I.for $\operatorname{EXP}(B)$} \\
\hline & & & & & & & & Lower & Upper \\
\hline \multirow{5}{*}{$\begin{array}{l}\text { Step } \\
1^{\mathrm{a}}\end{array}$} & $\mathrm{X} 1$ & .134 & .110 & 1.488 & 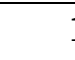 & .223 & 1.143 & .922 & 1.418 \\
\hline & $\mathrm{X} 2$ & .081 & .026 & 9.697 & & .002 & 1.084 & 1.031 & 1.141 \\
\hline & X3 & 1.060 & .517 & 4.202 & & .040 & 2.886 & 1.048 & 7.950 \\
\hline & $\mathrm{X} 4$ & -.120 & .139 & .743 & 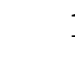 & .389 & .887 & .676 & 1.165 \\
\hline & Constant & 2.185 & 4.002 & .298 & . & .585 & 8.892 & & \\
\hline
\end{tabular}

Sumber: Data Olahan Peneliti (2019) 
Tabel 1 menunjukkan bahwa debt to equity ratio (X1) memiliki tingkat signifikansi sebesar $0,223>0,05(a=5 \%)$. Debt to equity ratio tidak berpengaruh terhadap ketepatan waktu pelaporan keuangan. Hasil penelitian ini tidak sesuai dengan hasil penelitian yang dilakukan oleh Sanjaya dan Wirawati (2016), Dewi dan Jusia (2013), Novatiani dan Asi (2016), serta Putri (2015) yang menyatakan bahwa Ketepatan waktu pelaporan keuangan terbukti dipengaruhi oleh debt to equity ratio. Hasil penelitian ini sejalan dengan Budiyanto dan Aditya (2015) dan Utami dan Yennisa (2017) yang menyatakan bahwa debt to equity ratio terbukti secara empiris tidak dapat mempengaruhi publikasi pelaporan keuangan secara tepat waktu. Debt to equity ratio menunjukkan besarnya risiko, disisi lain angka debt to equity ratio yang tinggi mengindikasikan kemampuan perusahaan yang baik dalam mengelola hutangnya. Kondisi perekonomian saat ini yang dihadapi perusahaan pertambangan dengan posisi jumlah utang bukan dipandang sebagai masalah yang luar biasa. Hal ini menunjukkan potensi informasi jumlah utang diabaikan oleh perusahaan apabila tata kelola perusahaan baik dan kinerja perusahaan masih dalam kondisi baik.

Profitabilitas (X2) memiliki tingkat signifikansi sebesar 0,002 $<0,05$ (a $=5 \%$ ). Hal ini berarti profitabilitas berpengaruh terhadap ketepatan waktu pelaporan keuangan. Hasil penelitian ini sesuai dengan hasil penelitian yang dilakukan oleh Sanjaya dan Wirawati (2016), Dewi dan Wirakusuma (2014), Toding dan Wirakusuma (2013), Oktarini dan Wirakusuma (2014), dan Putri (2015) yang menyatakan bahwa perusahaan yang menyajikan laporan keuangannya tepat waktu terbukti juga dipengaruhi oleh profitabilitas. Perusahaan yang memiliki profitabilitas tinggi akan menyampaikan laporan keuangan tahunannya tepat waktu karena merasa ada berita baik (goodnews) dalam laporannya. Perusahaan yang memiliki tingkat profitabilitas yang lebih tinggi membutuhkan waktu yang lebih cepat dalam pengauditan laporan keuangan karena harus secepatnya menyampaikan kabar baik kepada publik.

Pergantian auditor (X3) memiliki tingkat signifikansi sebesar 0,040 < $0,05(\mathrm{a}=5 \%)$. Hal ini berarti pergantian auditor berpengaruh terhadap penyajian pelaporan keuangan secara tepat waktu. Hasil penelitian ini sesuai dengan hasil penelitian yang dilakukan oleh Sanjaya dan Wirawati (2016), Budiyanto dan Aditya (2015), Hamidah dan Fajarwati (2015), dan Carbaja dan Yadnyana (2015) membuktikan pergantian auditor berpengaruh terhadap pelaporan keuangan yang tepat waktu.

Hal ini berarti terjadinya pergantian auditor justru memicu perusahaan untuk menyiapkan laporan keuangan dengan lebih baik jika dibandingkan ketika perusahaan masih diaudit oleh auditor sebelumnya. Perusahaan yang melakukan pergantian auditor terutama dari KAP Non Big Four ke KAP Big Four diyakini akan menyampaikan laporan keuangan lebih baik karena KAP Big Four dianggap public memiliki kompetensi auditor dan reputasi yang bagus serta sangat ketat dalam pelaksanaan regulasi.

Tingkat signifikansi Ukuran perusahaan (X4) yaitu sebesar 0,389 > $0,05(\mathrm{a}=5 \%)$. Berdasarkan hal tersebut dapat disimpulkan bahwa H5 ditolak. Hal ini berarti ukuran perusahaan tidak berpengaruh terhadap ketepatan waktu pelaporan keuangan. Hasil penelitian ini tidak sesuai dengan hasil penelitian yang dilakukan oleh Sanjaya dan Wirawati (2016), Toding dan Wirakusuma (2013), Oktarini dan Wirakusuma (2014), Novatiani dan Asi (2016), serta Utami dan Yennisa (2017) yang menyatakan bahwa ukuran perusahaan berpengaruh terhadap ketepatan waktu pelaporan keuangan. Hasil penelitian ini mendukung hasil penelitian Dewi dan Jusia (2013) dan Budiyanto dan Aditya (2015) yang menyatakan bahwa ukuran perusahaan 
tidak berpengaruh terhadap ketepatan waktu pelaporan keuangan. Meskipun perusahaan besar memiliki sumber daya yang memadai untuk menyampaikan laporan keuangan secara tepat waktu, disisi lain perusahaan besar juga memiliki kompleksitas transaksi yang besar. Koefisien determinasi ditunjukkan dengan nilai Nagelkerke $R$ Square, pengujian ini dilakukan untuk mengetahui seberapa besar variabel independen maupu menjelaskan dan mempengaruhi variabel dependen. nilai Nagelkerke R. Square sebesar 0,211 yang artinya kemampuan variabel independen dalam menjelaskan variabel dependen adalah sebesar 0,211 atau 21,1\%, sedangkan sisanya sebesar $78,9 \%(100 \%$ - 21,1\%) dijelaskan oleh variabel-variabel lain diluar model penelitian, seperti opini auditor, ukuran KAP, struktur kepemilikan, likuiditas, komite audit, kompleksitas operasi perusahaan, dan lainnya.

\section{SIMPULAN}

Kesimpulan yang dapat diperoleh dari hasil penelitian ini antara lain yaitu debt to equity ratio, profitabilitas, pergantian auditor, dan ukuran perusahaan secara simultan berpengaruh terhadap ketepatan waktu pelaporan keuangan. Secara parsial, profitabilitas dan pergantian auditor berpengaruh terhadap ketepatan waktu pelaporan keuangan, sedangkan debt to equity ratio dan ukuran perusahaan tidak berpengaruh terhadap ketepatan waktu pelaporan keuangan. Penelitian selanjutnya yaitu memperluas sampel penelitian yang digunakan (tidak terbatas pada perusahaan pertambangan yang terdaftar di Bursa Efek Indonesia saja), memperpanjang periode penelitian sehingga dapat melihat kecenderungan yang terjadi dalam jangka panjang dan menggambarkan kondisi yang sesungguhnya terjadi, dan menambah variabel penelitian yang diduga dapat mempengaruhi ketepatan waktu pelaporan keuangan.

\section{DAFTAR PUSTAKA}

Aprianti, I. (2017). Pengaruh Ukuran Perusahaan, Profitability, DAN Debt Equity Ratio Terhadap Ketepatan Waktu Pelaporan Keuangan (Studi Pada Perusahaan Sektor Industri Food And Beverages Dan Sektor Industri Tekstile Yang Terdaftar Di Bursa Efek Indonesia). Jurnal Ekonomi, Bisnis \& Entrepreneurship, 11(1), 37-46. Retrieved from www.idx.co.id

Belkaoui, A. R. (2006). Teori Akuntansi Buku 1 (5th ed.). Jakarta: Salemba Empat.

Brigham, E. F., \& Houston, J. F. (2010). Dasar-Dasar Manajemen Keuangan Buku 1 (11th ed.). Jakarta: Salemba Empat.

Budiyanto, S., \& Aditya, E. M. (2015). Faktor-Faktor yang Memengaruhi Ketepatan Waktu Pelaporan Keuangan (Studi Empiris Perusahaan Food and Beverages Periode 2010-2012). Fokus Ekonomi, 10(1), 77-87.

Carbaja, L. K. I. C., \& Yadnyana, I. K. (2015). Pengaruh Profitabilitas, Ukuran Perusahaan, Reputasi KAP, dan Pergantian Auditor pada Ketidaktepatwaktuan Pelaporan Keuangan. E-Jurnal Akuntansi Universitas Udayana, 13(2), 615-624.

Dewi, I. G. A. R. P., \& Wirakusuma, M. G. (2014). Fenomena Ketepatwaktuan Informasi Keuangan dan Faktor yang Mempengaruhi di Bursa Efek Indonesia. E-Jurnal Akuntansi Universitas Udayana, 8(1), 171-186.

Dewi, S. P., \& Jusia. (2013). Faktor- Faktor Yang Mempengaruhi Ketepatan Waktu Penyampaian Laporan Keuangan pada Perusahaan Real Estate dan Property yang Terdaftar di BEI. Jurnal Akuntansi, XVII(03), 368384. 
Hartono, J. (2017). Teori Portofolio dan Analisis Investasi. Yogyakarta: BPFE.

Jatmiko, A. (2018). BEI perpanjang suspensi delapan emiten. Retrieved from kontan.co.id website: https://investasi.kontan.co.id/news/beiperpanjang-suspensi-delapan-emiten

Kasmir. (2010). Pengantar Manajemen Keuangan. Jakarta: Kencana.

Noviatiani, R. A., \& Asri, N. P. (2016). Pengaruh Leverage, Ukuran Perusahaan, Opini Auditor dan Kompleksitas Operasi Perusahaan Terhadap Ketepatan Waktu Penyampaian Laporan Keuangan Perusahaan. Jurnal Akuntansi Bisnis Dan Ekonomi, 2(1), 417-430.

Oktarini, N. M. L., \& Wirakusuma, M. G. (2014). Analisis Faktor-Faktor Yang Memengaruhi Ketidaktepatwaktuan Pelaporan Keuangan. E-Jurnal Akuntansi Universitas Udayana, 7(3), 648-662.

Putri, A. I. (2015). Berbagai Faktor Yang Mempengaruhi Ketepatan Waktu Pelaporan Keuangan. Jurnal Ilmu Dan Riset Akuntansi, 4(7).

Sanjaya, I. M. D. M., \& Wirawati, N. G. P. (2016). Analisis Faktor-Faktor yang Mempengaruhi Ketepatan Waktu Pelaporan Keuangan pada Perusahaan Manufaktur yang Terdaftar di BEI. E-Jurnal Akuntansi Universitas Udayana, 15(1), 17-26.

Sukirno. (2015). BEI Suspensi 6 Emiten. BORN, BUMI, BRAU Termasuk. Retrieved from market.bisnis.com website: https://market.bisnis.com/read/20150630/192/448571/bei-suspensi6-emiten.-born-bumi-brau-termasuk

Sulistiyono, S. T. (2016). BEI Bekukan 18 Emiten karena Membandel Tak Serahkan Laporan Keuangan. Retrieved from tribunnews.com website: http://www.tribunnews.com/bisnis/2016/06/30/bei-bekukan-18emiten-karena-membandel-tak-serahkan-laporan-keuangan

Suprayitno, D. (2017). BEI suspensi perdagangan saham 17 emiten. Retrieved from kontan.co.id website: https://investasi.kontan.co.id/news/beisuspensi-perdagangan-saham-17-emiten

Toding, M., \& Wirakusuma, M. G. (2013). Faktor-Faktor Yang Memengaruhi Ketepatwaktuan Penyampaian Laporan Keuangan. E-Jurnal Akuntansi Universitas Udayana, 3(2), 318-333.

Utami, D., \& Yennisa. (2017). Faktor-Faktor Mempengaruhi Ketepatan Waktu Pelaporan Keuangan pada Perusahaan Sub Sektor Bank di Bursa Efek Indonesia. Akuntansi Dewantara, 1(1), 31-38. 